\title{
SMALL MAMMALS
}

\section{IN ASPEN CLEARCUTS}

HUGH M. HUNT, Wildlife Research Division, Dept. of Tourism and Renewable Resources, 2602 - 8th Street East, Saskatoon, Saskatchewan, S7H OV7.

Small mammals are an important bart of the trembling aspen Populus remuloides forest ecosystem. An understanding of the reaction of these animals to alteration of their habitat hrough clearcut logging is valuable knowledge that can be added to the growing amount of information about the effect of logging on wildlife species.

Approximately 1,400 ha $(3,500$ acres) of mature aspen forest in the Pasquia-Porcupine region of Saskatchewan (Fig. 1) are clearcut annually for the production of waferboard. Research into the effect of this clearcutting on wildlife population has been ongoing for the past several years but most of the effort has been directed toward the resident big game species. This preliminary study of small mammal populations on the clearcuts and in the adjacent mature forests was conducted in an effort to obtain a more complete knowledge of the ecological effects of forest cutovers.

\section{Study Area}

Small mammal trapping was carried out in three locations in the Piwei cutting block in the Porcupine Provincial Forest about $55 \mathrm{~km}$ southwest of Hudson Bay, Saskatchewan (Fig. 1). The Piwei cutting block is a series of recent clearcuts $(<10$ years bld) in the mature aspen stands characterizing this area. Some mixedwood stands (aspen - white spruce Picea glauca) and pure softwood stands are also found in this ocale.

\section{TRAP AREA A}

This trap area consisted of a 3year-old cutover and adjacent mature aspen forest. In the three years since logging, aspen suckering had resulted in a dense stand of aspen approximately $2 \mathrm{~m}$ high overtopping a shrub layer of beaked hazelnut Corylus cornuta and a modest herb stratum. Tops of numerous felled trees had been left in the cutover as slash.

The adjacent mature stand had an aspen - balsam poplar Populus balsamifera overstory about $20 \mathrm{~m}$ high with a canopy density of 80-100 percent. The shrub stratum under this canopy consisted of moderate amounts of high-bush cranberry Viburnum trilobum, beaked hazelnut and speckled alder Alnus rugosa; the ground cover was primarily leaf litter.

\section{TRAP AREA $B$}

This trap area consisted of a 1year-old cutover and the adjacent mature forest. The cutover was characterized by aspen sprouts about $0.5 \mathrm{~m}$ high and a limited herb stratum; total ground cover was approximately 50 percent. Tops of the aspens removed during logging dotted the cutover.

The mature stand, situated at the top of the Piwei River valley, was on terrain with a slope of about $20^{\circ}$. Over-story was $20 \mathrm{~m}$ high aspen and the moderately dense shrub understory was composed primarily of beaked hazelnut. Ground cover was mostly leaf litter and bunchberry Cornus canadensis. 


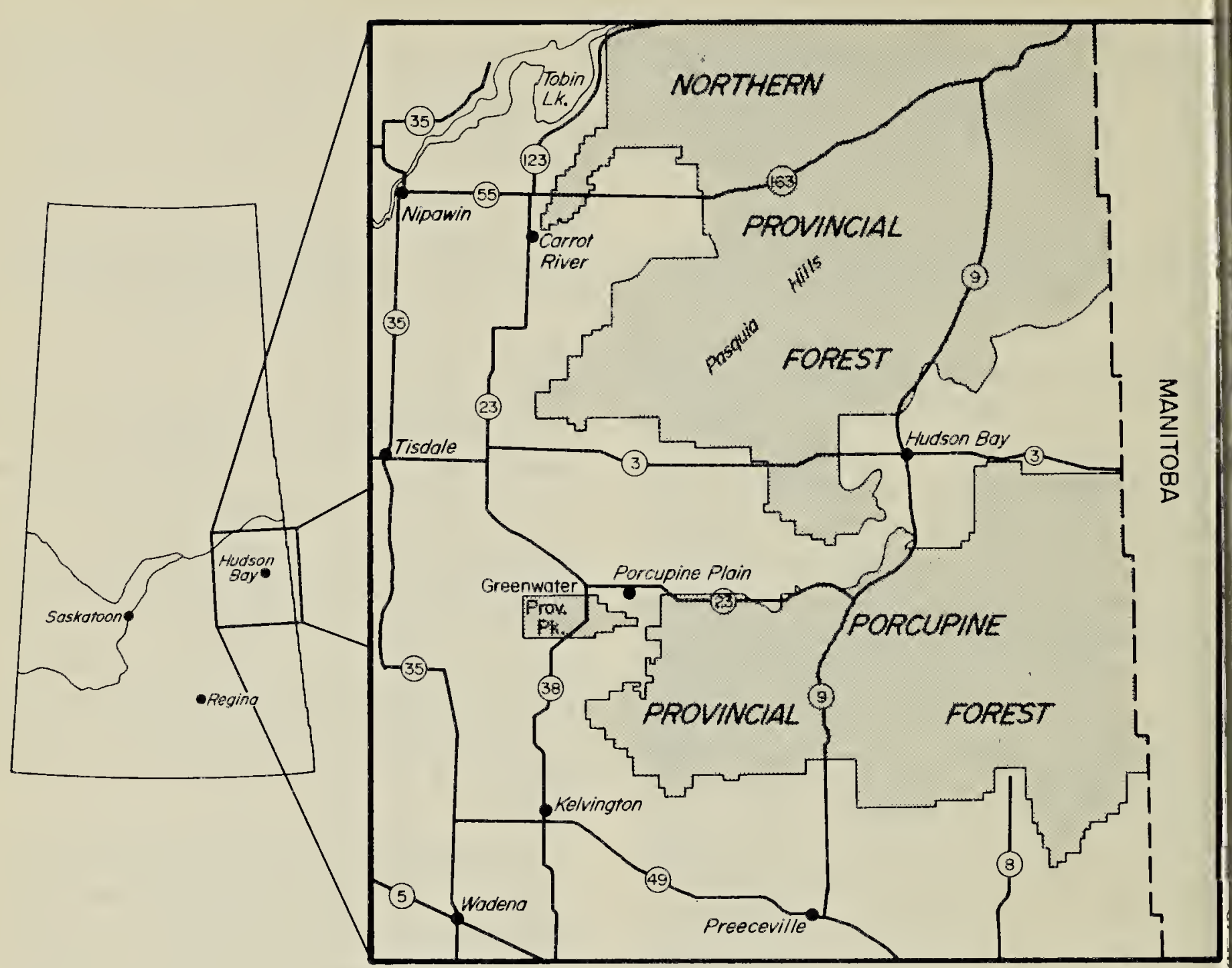

Figure 1. The Pasquia - Porcupine region of Saskatchewan.

\section{TRAP AREA C}

This trap area consisted of a 3year-old cutover and adjacent uncut forest. Before logging, the portion of the cutover in which the trapping took place had a white spruce component overtopped by the aspen canopy. This spruce stratum was left when the aspen was removed and some of the trees had subsequently blown down. The cutover was a tangle of fallen spruce, aspen tops and limited amounts of sprouting aspen. Ground vegetation varied from moderate amounts of forbs and grasses under the sprouting aspen to dense stands of grasses and sedges Carex spp. in the spruce-dominated parts of the trap area.

The uncut stand adjacent to the cutover was a mixed aspen - white spruce stand with the aspen overtopping the spruce. The shrub stratum was sparse and principal ground cover was leaf litter, particularly in those portions where spruce predominated.

\section{Methods}

On each of the three trap areas, two lines of 30 snap-traps each were employed; one line was located on the cutover and one line in the adjacent mature forest. Three traps were set at each station with about $10 \mathrm{~m}$ between stations resulting in a 10-station trap line about $100 \mathrm{~m}$ in length. Trapping on each area took place on two consecutive nights yielding a total of 60 trap-nights per line and 120 trap-nights per area. Traps were baited with peanut butter and checked every 24 hours. 
TABLE 2. Catch/Effort with Correction for Sprung Traps.

\begin{tabular}{|c|c|c|c|c|c|c|}
\hline & $\begin{array}{r}\text { CE }(\% \\
\text { TRAP AR }\end{array}$ & b) & $\begin{array}{r}\text { CE }(\% \\
\text { TRAP AR }\end{array}$ & 6) & $\begin{array}{r}\text { CE }(\% \\
\text { TRAP AR }\end{array}$ & $\begin{array}{l}\text { \%) } \\
\text { REA C }\end{array}$ \\
\hline Species & $\begin{array}{c}\text { Mature } \\
\text { Forest }\end{array}$ & Cutover & $\begin{array}{c}\text { Mature } \\
\text { Forest }\end{array}$ & Cutover & $\begin{array}{c}\text { Mature } \\
\text { Forest }\end{array}$ & Cutor \\
\hline Clethryonomys gapperi & 18.4 & 48.1 & 18.8 & 33.0 & 9.4 & \\
\hline $\begin{array}{l}\text { Peromyscus } \\
\text { maniculatus }\end{array}$ & 2.3 & 12.7 & 10.4 & 6.2 & 1.9 & \\
\hline $\begin{array}{l}\text { Microtus } \\
\text { pennsylvanicus }\end{array}$ & - & - & 2.1 & 2.1 & - & \\
\hline Sorex cinereus & 4.6 & 2.5 & - & - & - & \\
\hline Blarina brevicauda & - & 2.5 & - & - & - & \\
\hline All Species & 25.3 & 65.8 & 31.3 & 41.3 & 11.3 & \\
\hline
\end{tabular}

about half those levels in trap area $C$. Deer mouse captures and CE in the uncut areas were similar in trap areas $A$ and $C$ but much higher in trap area $B$. The only masked shrews trapped in the uncut portions were caught in trap area $A$.

In the cutover portions of the trap areas, red-backed voles were trapped most frequently in trap areas $A$ and $C$ and least frequently in trap area B. Trapping frequency of deer mice was highest in trap area $A$ and lowest in trap area $C$. The largest capture of meadow voles occurred in the cutover portion of trap area C. The only masked shrew and shorttailed shrew captured in a cutover were trapped in area $A$.

\section{Discussion}

Higher capture totals and CE for small mammals on the cutovers as compared to the adjacent uncut stands indicates clearcut logging improved the habitat of aspendominated areas for small mammals. Increases in small mammal populations after logging have been documented in studies of Douglas-fir Pseudotsuga menziesii forests in
California and Oregon 133 and hare wood and boreal coniferous forest in West Virginia, 6 wherea population densities have remaine more or less constant after loggin upland black spruce Picea marian stands in Ontario 9 and hardwoo forests in New York. ${ }^{8}$

A simplified explanation of im proved habitat after logging woul be greater availability of food an cover. The cutover portions of th three trap areas had a ground cove of herbs, low shrubs and loggin slash that was generally superior a small mammal habitat, even in the year-old cutover, to that of the uncl portions. Several authors 13137 hav described the food of deer mice consisting primarily of seeds and ir sects and the food of red-backe voles as mostly succulent plant part and some seeds. The rapid recover and proliferation of the vegetation $i$ the aspen clearcuts of the three tra areas presumably resulted in in creased food supplies, particularl for red-backed voles, and bette cover conditions than were availabl in the uncut stands. Lower trap total and $C E$ for the cutover portion of tra 
area $B$ than for the other two cutover trap areas were probably because the short interval since logging (one year) limited vegetative recovery in the cutover resulting in habitat conditions inferior to those in the 3-yearold cutovers. However, habitat conditions in the 1-year-old cutover were still superior to those of the uncut stands.

Capture totals and CE for the uncut portions of the three trap areas indicated the mixedwood stand (trap area $\mathrm{C}$ ) had the lowest small mammal population, presumably because the sparse ground cover under this stand provided poor food and cover conditions. The uncut portion of trap area B may have been better small nammal habitat than the uncut porfion of trap area A because of denser shrub and herb layers.

The most noticeable change in the mall mammal population following clearcutting was in the density rather han composition. Apparently, both incut and clearcut habitats were best for red-backed voles as they nade up the major proportion of the mall mammal populations in each abitat. Deer mice, trapped in low roportions in both the clearcuts and incut areas, must have been limited the hardwood-dominated areas. he lack of change in population omposition after logging is contrary the findings of studies of small ammals after logging Douglas-fir rests, $13 \quad 34$ black spruce forests, 9 ack pine Pinus banksiana forests in lanitoba12 and mixed coniferardwood forests in Minnesota. ${ }^{7}$ hese studies reported a decrease in d-backed voles and an increase in eer mice after clearcutting, likely as result of a lack of cover making the learcuts unsuitable for red-backed les. The rapid vegetative recovery the aspen cutovers in this study obably meant the period when a ck of cover was limiting red-backed

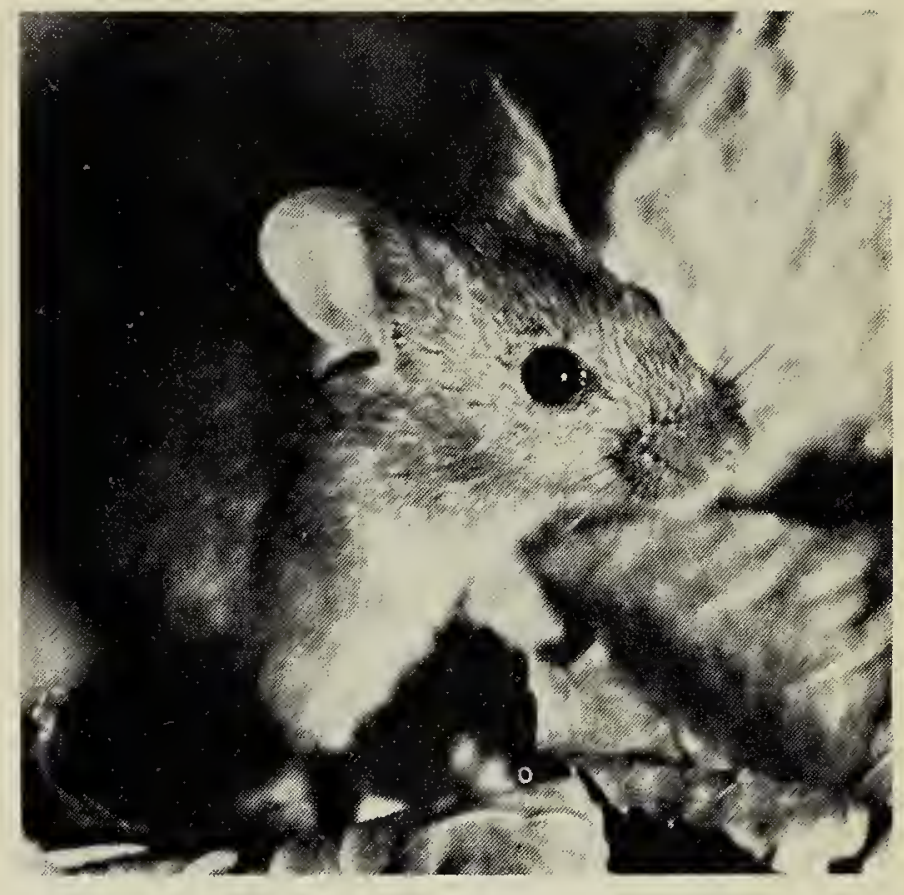

Deer mouse

Wayne Lynch

voles had already passed by the end of the first complete growing season after clearcutting. Because the vegetative composition of recent aspen clearcuts closely resembles that of mature aspen stands, 5 major changes in the small mammal population composition would not be expected.

Meadow vole capture totals were highest in the cutover portion of trap area $\mathrm{C}$ characterized by extensive grass and sedge cover. Martell and Radvanyi 9 felt meadow vole microdistribution and density were correlated to the amount of moist, graminoid cover present. Banfield 2 describes the typical habitat of masked and short-tailed shrews as moist forests; the few individuals of these species captured during the study were trapped on trap area $A$, the moistest of the three trap areas.

Numerous studies have demonstrated the role of small seed-eating mammals in hindering regeneration of coniferous trees of commercial importance (see Pank ${ }^{11}$ ). In particular, mice have been found to be partly responsible for natural seeding failure after logging or fires and they often make artificial 
seeding difficult or impossible. Because aspen regenerates after logging or fires primarily by suckering from the existing root system, seed-eating small mammals are probaby of little importance in affecting revegetation of aspen cuts or burns. However, small mammals could conceivably affect regeneration of white spruce after logging mixedwood stands like that characterizing trap area $C$.

Although small mammals in an aspen-dominated forest habitat do not appear to be of direct economic importance to man, they are an integral part of the food chains or webs that characterize all biotic communities. In simplified terms, producers (plants) in the aspen community are eaten by primary consumers (herbivores such as redbacked voles and deer mice) which are in turn eaten by the secondary consumers (carnivores) such as redtailed hawks, broad-winged hawks, short-tailed weasels and coyotes. Through these interrelationships of the food web in the aspen forest, small mammals can directly and indirectly influence the floral and faunal characteristics of the community to a significant degree.

\section{Acknowledgements}

This study was part of a program investigating the influence of forest cutting on wildlife in Saskatchewan conducted by the Wildlife Research Division of the Department of Tourism and Renewable Resources. I am indebted to D. Dobson, L. Koback, I. McMurchy, G. W. Pepper and B. R. Neal for their assistance.

1AHLGREN, C. E. 1966. Small mammals and reforestation following prescribed burning. J. Forestry 64(4):614-618.

2BANFIELD, A. W. F. 1974. The mammals of Canada. Univ. of Toronto Press. Toronto. 438 pp.

${ }^{3}$ GASHWILER, J. A. 1959. Small mammal study in southwest Oregon. J. Mammal. 40(1):128-139.

${ }^{4}$ GASHWILER, J. A. 1970. Plant and mammal changes on a clearcut in west-central Oregon. Ecology 51(6): 1018-1026.

5 HUNT, H. M. 1977. Browse succession in an aspen forest. Sask. D.T.R.R. Wildlife Technical Report series 77 39. $86 \mathrm{pp}$.

6KIRKLAND, G. L. Jr. 1977. Responses of small mammals to the clearcutting of northern Appalachian forests. J. Mammal. 58(4):600-609.

7 KREFTING, L. W. and C. E. AHLGREN. 1974. Small mammals and vegetation changes after fire in a mixed conifer. hardwood forest. Ecology 55(6):1391. 1398.

8KRULL, J. N. 1970. Small mamma populations in cut and uncut northern forests. New York Fish and Game Journal. 17(2): 128-130.

9MARTELL, A. M. and A. RADVANYI 1977. Changes in small mammal populations after clearcutting o northern Ontario black spruce forest Can. Field-Natur. 91:41-46.

10NELSON, L. Jr. and F. W. CLARK. 1973 Correction for sprung traps in catch/effort calculations of trapping results. J. Mammal. 54(1):295-298.

11PANK, L. F. 1974. A bibliography on seed-eating mammals and birds tha affect forest regeneration. U.S.D.I. Fish and Wildlife Service, Spec. Sci Rep., Wildl. No. 174. 28 pp.

12SIMS, H. P. and C. H. BUCKNER. 1973 The effect of clearcutting and burn ing of Pinus banksiana forests on the populations of small mammals in southeastern Manitoba. Am. Midl Nat. 90(1):228-231.

13TEVIS, L., JR. 1956. Responses of smal mammal populations to logging 0 Douglas-fir. J. Mammal. 37(2):189-196 